\title{
PENGARUH KEPEMIMPINAN KEPALA SEKOLAH DAN PENGELOLAAN KEPEGAWAIAN TERHADAP PENANGGULANGAN STRES GURU PADA SEKOLAH MENENGAH ATAS DI SUB RAYON 11 PARUNG KABUPATEN BOGOR
}

\author{
Muhammad Mudzakkir \\ Sekolah Tinggi Agama Islam Nurul Iman Parung-Bogor \\ Jl. Nurul Iman No. 01 Ds. Waru Jaya Rt 01/01. Kec. Parung. Kab. Bogor \\ Email: muhammadmudzakkir99@gmail.com
}

\begin{abstract}
This research aims to know and test the empirical data related to the influence of the leadership of the principal and the management of personnel against the management of stress teachers separately as well as simultaneously. In this research, the authors use quantitative methods with the corelasional approach towards quantitative data obtained from research object i.e. High school teachers in sub 11 rayon parung bogor Regency. The sample of this research is as much as 104 respondents out of a total population of 140 private high school teacher in sub 11 rayon parung bogor Regency. Data collection is done using an engineering question form/questionnaire. This type of analysis is the analysis of correlation and regression are spelled out in the descriptive. The results of this research are:

First, There is a positive and significant influence among the leadership of the principal against stress management teacher the correlation coefficient of 0.660 and coefficient of determination $\mathrm{R}^{2}$ of 0.436 which give influence on stress management teacher of $43.6 \%$. and the remaining $56.4 \%$ determined by other factors. Koefesien regression obtained $\hat{\mathrm{Y}}=55.886+0.531 \mathrm{X}_{1}$ means that every increase of one unit of score leadership principals affect improvement score of teacher stress management 0.531 .

Second, There are a positive and significant influence between the management of the staffing against stress management teacher with the correlation coefficient of 0,694 and the coefficient of determination $\mathrm{R}^{2}$ of 0,481 that gives the effect on stress management teacher of $48.1 \%$ and the rest that is $51.9 \%$ determined by other factors. Koefesien regression obtained $\hat{Y}=50.334+0.572 \mathrm{X}_{2}$ means that each increase of one unit of score management staffing affects improvement score of teacher stress management 0.572 .

Third, There are a positive and significant influence among the leadership of the principal and management staffing together-the same against stress management teacher with koefisen correlation $=0.706$ and koefesien determination of $\mathrm{R}^{2}$ of 0,499 that influence is simultaneously against stress management teacher of $49.9 \%$ and the rest i.e. $50.1 \%$ is determined by other factors. Koefesien regression obtained $\hat{\mathrm{Y}}=$ $47.229+0.205 \mathrm{X}_{1}+0.394 \mathrm{X}_{2}$ means every one unit increase in score independent leadership of the principal and the management of personnel in simultaneously affect the improvement of teacher's stress management score $0.205+0.394=0.599$.
\end{abstract}

Keywords: The Leadership Of The Principal, Management Of Employment, Stress Management Teacher. 


\begin{abstract}
Abstrak
Penelitian ini bertujuan untuk mengetahui dan menguji data-data empirik terkait pengaruh kepemimpinan kepala sekolah dan pengelolaan kepegawaian terhadap pengelolaan stress guru secara terpisah maupun simultan. Dalam penelitian ini, penulis menggunakan metode kuantitatif dengan pendekatan korelasional terhadap data-data kuantitatif yang diperoleh dari objek penelitian yaitu guru-guru SMA di sub rayon 11 parung kabupaten bogor. Sampel penelitian ini adalah sebanyak 104 responden dari total populasi 140 guru SMA swasta di sub rayon 11 parung kabupaten bogor. Pengumpulan data dilakukan dengan menggunakan teknik angket/ kuesioner. Jenis analisis yang digunakan adalah analisis korelasi dan regresi yang dijabarkan secara deskriptif. Hasil dari penelitian ini adalah:

Pertama, Terdapat pengaruh positif dan signifikan antara kepemimpinan kepala sekolah terhadap penanggulangan stres guru dengan koefisien korelasi sebesar 0,660 dan koefisien determinasi $\mathrm{R}^{2}$ sebesar 0,436 yang memberikan pengaruh terhadap pengelolaan stres guru sebesar $43,6 \%$. dan sisanya $56,4 \%$ ditentukan oleh faktor lainnya. Koefesien regresi diperoleh $\hat{Y}=55,886+0,531 \mathrm{X}_{1}$ artinya setiap peningkatan satu unit skor kepemimpinan kepala sekolah mempengaruhi peningkatan skor penanggulngan stres guru sebesar 0,531.

Kedua, Terdapat pengaruh yang positif dan signifikan antara pengelolaan kepegawaian terhadap penanggulangan stres guru dengan koefisien korelasi sebesar 0 , 694 dan koefisien determinasi $\mathrm{R}^{2}$ sebesar 0,481 yang memberikan pengaruh terhadap penanggulangan stres guru sebesar 48,1\% dan sisanya yaitu 51,9\% ditentukan oleh faktor lainnya. Koefesien regresi diperoleh $\hat{\mathrm{Y}}=50,334+0,572 \mathrm{X}_{2}$ artinya setiap peningkatan satu unit skor pengelolaan kepegawaian mempengaruhi peningkatan skor penanggulangan stres guru sebesar0,572.

Ketiga, Terdapat pengaruh yang positif dan signifikan antara kepemimpinan kepala sekolah dan pengelolaan kepegawaian secara bersama- sama terhadap penanggulangan stres guru dengan koefisen korelasi $=0,706$ dan koefesien determinasi $\mathrm{R}^{2}$ sebesar 0,499 yang memberikan pengaruh secara bersamaan terhadap penanggulangan stres guru sebesar $49,9 \%$ dan sisanya yaitu $50,1 \%$ ditentukan oleh faktor lainnya. Koefesien regresi diperoleh $\hat{Y}=47,229+0,205 \mathrm{X}_{1}+0,394 \mathrm{X}_{2}$ artinya setiap peningkatan satu unit skor independen kepemimpinan kepala sekolah dan pengelolaan kepegawaian secara bersamaan mempengaruhi peningkatan skor penanggulangan stres guru sebesar $0,205+0,394=0,599$.
\end{abstract}

Kata Kunci: Kepemimpinan Kepala Sekolah, Pengelolaan Kepegawaian, Penanggulangan Stres Guru.

\title{
A. Pendahuluan
}

Dalam dunia pendidikan, keberadaan peran dan fungsi guru merupakan salah satu faktor yang sangat penting. Guru merupakan bagian terpenting dalam proses belajar-mengajar, baik di jalur pendidikan formal, nonformal maupun informal. Oleh sebab itu, dalam setiap upaya peningkatan kualitas pendidikan di tanah air guru tidak dapat dilepaskan dari berbagai hal yang berkaitan dengan eksisistensi mereka. Filosofi sosial budaya dalam pendidikan Indonesia, telah 
Pengaruh Kepemimpinan Kepala Sekolah dan Pengelolaan Kepegawaian Terhadap Penanggulangan Stres Guru ...

menenempatkan fungsi dan peran guru sedemikian rupa sehingga para guru di Indonesia tidak jarang telah di posisikan mempunyai peran ganda bahkan multifungsi.

Masalah guru menjadi sorotan karena guru merupakan unjung tombak dari setiap kebijakan dan kegiatan yang berkaitan dengan pendidikan. Gurulah yang melaksanakan secara operasiaonal segala bentuk pola, gerak dan geliatnya perubahan dalam dunia pendidikan. Ketika muncul berbagai model pembelajaran yang berkaitan dengan kurikulum misalnya, gurulah yang sangat berperan.

Tugas utama seorang guru adalah sebagai pendidik dan pengajar di sekolah. Seorang guru dituntut harus mampu mentransfer pengetahuan kepada anak didiknya melalui proses menjadikan anak didiknya dari tidak tau menjadi tau. Namun para guru dalam tugasnya menemui beberapa hambatan antara lain, sering bergantinya kurikilum serta tuntutan mengaplikasikannya dengan cepat, sedangkan dalam prosesnya membutuhkan kecakapan dan keterampilan yang memadai, beban kerja yang berat, tekanan dari atasan, kebutuhan hidup yang meningkat serta kurangnya penghargaan terhadap kinerja guru semua hal tersebut tidak lantas diimbangi dengan kesejahteraan yang layak yang diperoleh oleh seorang guru membawa para guru mengalami stres.

Pada tahun 2015 UKG dilaksanakn untuk menguji kompetensi guru pada dua bidang yaitu pedagogik dan profesional. Dari sekian banyak provinsi yang mengikuti UKG Sebanyak tujuh provinsi saja yang mendapat nilai terbaik. Penyelenggaraan uji kompetensi guru (UKG) tahun 2015. Nilai yang diraih tersebut merupakan nilai yang mencapai standar kompetensi minimum (SKM) yang ditargetkan secara nasional, yaitu rata-rata 55. Selain itu, beredar kabar bahwa jika hasil UKG dibawah Standar Kopetensi Minimum (SKM) yang sudah ditentukan akan menjadi tolak ukur memvonis guru layak atau tidak layaknya menjadi tenaga pengajar. Hal ini menandakan adanya penurunan kualitas dengan indikasi bulum tercapainya target UKG secara maksimal dan memicu stres yang dialami guru meningkat.

Selain masalah diatas ada permasalahan lain yang menerpa para guru, seperti yang disampaikan (Mendikbud), Muhadjir Effendi hingga saat ini ada sekitar 3 (tiga) juta guru yang menyebar di seluruh Indonesia. Di mana, lebih dari 600 ribu adalah guru Honorer dan semuanya menuntut untuk diangkat sebagai Pegawai Negeri Sipil (PNS) ucap dia kepada Liputan6.com, saat berkunjung ke Penukal 
Abab Lematang Ilir (PALI), Senin, 20 Maret 2017. Menurut dia, pemerintah tidak akan bisa mengangkat guru honorer secara besarbesaran. Sebab, anggarannya terbatas dengan jumlah guru yang sangat banyak.

Selain itu dalam upaya memajukan pendidikan disekolah bukan saja hanya guru yang bertanggung jawab tetapi semua stak eholders diantaranya yang lebih penting adalah kepala sekolah karna ia memilki peran yang sangat penting dalam pengelolaan sekolah. Majumundurnya kondisi sekolah dan tinggi rendahnya kualitas lulusannya tidak terlepas dari peran kepala sekolah. Mengenai besarnya tanggung jawab kepala sekolah Mortimer, J. Adler dalam Dadi Permadi mengatakan "The quality of teaching and learning that goes in a school is largely determind by the quality of principals leadership" ( mutu belajar mengajar yang terjadi di sekolah adalah ditentukan oleh sebagian besar mutu kepemimpinan kepala sekolah).

Dari uraian di atas peneliti tertarik untuk melakukan penelitian pengaruh kepemimpinan kepala sekolah dan pengelolaan kepegawaian terhadap penanggulangan stres guru pada Sekolah Menengah Atas Swasta di Sub Rayon 11 kecamatan Parung, Bogor.

\section{B. Kajian Teori}

\section{Penanggulangan Stres Guru}

Lingkungan bisa menjadi pemicu stres, misalnya orang yang terlalu takut akan kehilangan sesuatu yang menurutnya sangat berharga seperti takut ditinggalkan orang terdekat, kehilangan pekerjaan, takut kehilangan harta dan lainnya. Oleh karnanya Allah memberikan bimbingan agar manusia bisa bersabar dalam menghadapi permasalahan dan musibah yang menimpanya firman Allah dalam Surat al-Baqorah/ 02:155 sebagai berikut,

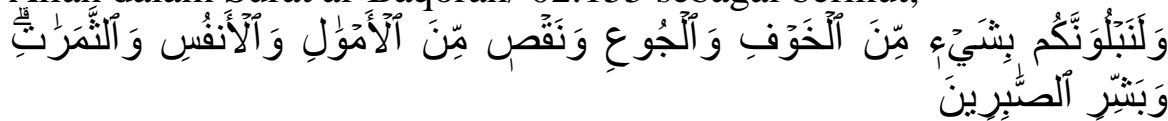

Dan sungguh akan Kami berikan cobaan kepadamu, dengan sedikit ketakutan, kelaparan, kekurangan harta, jiwa dan buah-buahan. dan berikanlah berita gembira kepada orang-orang yang sabar.(QS. alBaqorah/ 02:155)

Stres adalah masalah yang akhir-akhir ini hangat dibicarakan dan posisinya sangat penting dalam kaitannya dengan kinerja seseorang dalam sebuah organisasi. Dalam Kamus Besar Bahasa Indonesia Stres diartikan sebagai gangguan atau kekacauan mental 
Pengaruh Kepemimpinan Kepala Sekolah dan Pengelolaan Kepegawaian Terhadap Penanggulangan Stres Guru ...

dan emosional yang disebabkan oleh faktor dari luar. Beberapa ahli membahas dan mendifinisikan tentang stres sebagai berikut:

Stephen P. Robbins dan Timothy A. Judge mendefinisikan stres sebagai kondisi yang dinamis yaitu individu berkonfrontasi dengan peluang, tuntutan, atau sumber daya terkait dengan apakan individu inginkan dan yang mana hasil yang dipandang menjadi tidak pasti dan penting.

Kemudian Laurence Siegel dan Irving M. Lana dalam Darwis Hude." Stress is any condition that threatens the organism. We are here differentiatting between a challenge and threat. Challenges are presented by circumstensces with which the organism feel it can cope; thearts are presented by circumstensces with which the organism feel is cannot cope" Stres adalah kondisi yang mengancam organisme. Di sini kami membedakan antara tantangan dan ancaman. Tantangan dihadirkan oleh lingkungankeadaan dimana organisme mearasa dapat menanggulanginya; sedangkan ancaman dihadirkan oleh lingkungan keadaan dimana organisme merasa tidak dapat mengatasinya).

Fred Luthans mendefinisikan stress is define as an adaptive response to an external situation that results in physical, psychological, and/or behavior deviations for organizational participant. Stres didefinisikan sebagai respon adaptif terhadap situasi eksternal yang menghasilkan penyimpangan fisik, psikologis, dan / atau perilaku untuk peserta organisasi.

Beehr and Newman dalam Fred Luthans mendefinisikan stres kerja sebagai berikut Job Stress is a condition arising from the interaction of people and their jobs and characterized by changes within people that force them to deviate from their normal founctioning". Stres kerja adalah kondisi yang muncul dari interaksi individu dengan pekerjaannya dan ditandai dengan perubahanperubahan di dalam diri individu tersebut yang mendorongya untuk menyimpang dari fungsi normalnya.

a. Faktor-Faktor yang Mempengaruhi Stres

1) Faktor lingkungan

Faktor lingkuan merupakan salah satu sumber yang potensial menyebabkan stres. Faktor lingkungan seperti ketidakpastian lingkungan akan mempengaruhi bentuk dari tatanan struktur organisasi, hal ini juga mempengaruhi level stres diantaranya karyawan di dalam suatau organisasi, tentu saja, ketidak 
pastian merupakan alasan terbesar bagi individu yang memiliki masalah dalam mengatasi maslah perubahan dalam organisasional.

2) Faktor organisasional

Kelompok kedua adalah faktor organisasional, faktor tersebut memberikan peranan sebagai salah satu sumber dari stres individu.

3) Faktor Individu

Katagori ketiga adalah faktor individu, katagori yang terakhir ini adalah adalah factor-faktor pribadi dari tenaga kerja seperti: permasalahan keluarga, permasalahan dalam ekonomi rumah tangga, dan karekteristik kepribadian, kesulitan pernikahan putusnya hubungan yang dekat dan permaslahan kedisiplinan dengan anak-anak dapat menciptakan stres pada karyawan sering kali permasalahan tersebut tidak bisa dapat ditinggalkan dan terbawa sampai kepintu depan ketika mereka sampai di tempat kerja.

b. Gejala Stres

Berkenaan dengan stres, Stephen P. Robbins dan Timothy A. Judge membagi gejala stres kedalam tiga gejala stres, antara lain: (1) gejala fisiologis ( sakit-sakitan, tekanan darah tinggi, penyakit arteri coroner, nyeri punggung dan nyeri perut). Memberikan kesimpulan bahwa stres dapat meninbulkan perubahan metabolisme, meningkatkan fungsi jantung dan tekanan darah, membawa sakit kepala dan menyebabkan serangan jantung, (2) gejala psikologis diawali ketidak puasan terhadap pekerjaan merupakan penyebab yang sangat jelas dari stres sehingga menimbulkan depresi, gelisah, lekas marah, pelupa, kitidak mampuan untuk berpikir jernih, kurang percaya diri , kelelahan, kebosanan dan penundaan, (3) gejala prilaku stres yang terkait prilaku adalah meliputi penurunan produktivitas, ketidak hadiran, demikian pula dengan perubahan dalam kebiasaan makan, meningkatnya merokok, mengkonsumsi alkohol dan obat-obatan, makan berlebihan dan gangguan tidur.

c. Jenis-Jenis Stres

Permasalahan stres banyak menjadi hambatan dan keluahan kebanyakan orang, karena stres jika tidak diatasi dengan bijak dan tepat akan mengganggu setiap aktifitas seseorang. Untuk menghindari permaslah stres tersebut perlu dikenali jenisjenis stres, berikut ini beberapa jenis stres yang ada. 
Pengaruh Kepemimpinan Kepala Sekolah dan Pengelolaan Kepegawaian Terhadap Penanggulangan Stres Guru ...

1) Stres Positif. Stres tidak hanya dipicu sepenuhnya oleh pengalaman negatif. Bahkan, pengalaman positif juga dapat membawa stres, seperti upacara kelulusan atau pernikahan. Namun, tipe stres seperti ini dalam kadar yang dapat diatasi sebenarnya baik untuk sistem imun kita. Selain itu, tipe stres ini juga dapat membuat banyak orang lebih mudah untuk menciptakan tujuan dan menikmati proses mencapainya dengan penuh energi.

2) Distres Internal. Stres model ini adalah tipe stres yang tidak baik. Distres merupakan tipe stres negatif hasil dari pengalaman di masa lalu yang buruk, ancaman, atau perubahan situasi yang tidak terduga dan tidak nyaman.

3) Distres akut terjadi ketika seseorang mengalami distres yang dipicu oleh peristiwa buruk yang berlalu dengan cepat.

4) Hipostres. Hipostres merupakan "ketidakadaan" stres, tetapi bisa juga diartikan kebosanan yang ekstrem.

5) Eustres. Eustres merupakan stres yang sangat berguna lantaran dapat membuat tubuh menjadi lebih waspada.

d. Penanggulangan Stres

Stepen P. Robbins. Mengemukakan bahwa ada dua cara untuk menanggulangi stres, yaitu pendekatan individu dan pendekatan organisasi. Perbedaan pendekatan individu dan organisasi dalam mengelola stres, seperti penjelasan berikut,

1) Pendekatan Individu

Strategi individu yang lebih efektif mencakup pelaksanaan teknik, menejemen waktu, meningkatkan latihan fisik, pelatihan relaksi, dan memperluas jaringan dukungan sosial.

2) Pendekatan organisasional.

Startegi yang mungkin perlu dipertimbangakan oleh menejemen atara lain perbaikan seleksi anggota dan penempatan kerja, penetapan target yang realistis perancangan ulang pekerjaan, peningkatan keterlibatan karyawan, perbaikan komunikasi organisasi dan penegakan program kesejahteraan korporasi.

3) Melakukan Terapi

Terapi adalah treatmen baik bersifat fisik maupun psikis. Terapi yang bersifat pisikis disebut psikoterapi, terapi dapat juga berarti semua bantuan yang diberikan oleh orang yang 
ahli kepada orang yang membutuhkan batuan dalam situasi yang sulit.

Dengan demikian dapat disintesakan bahwa penanggulangan stres guru adalah upaya mengatasi kondisi ketegangan yang muncul dari interaksi individu (guru) dengan pekerjaannya dan ditandai dengan perubahan-perubahan pada fisik, psikologis, dan / atau perilaku di dalam diri individu tersebut yang memaksanya untuk menyimpang dari fungsi normalnya. Adapun indikatornya (1) adanya tekanan dan ancaman di tempat kerja, (2) Beban Kerja yang berlebihan (3) konflik sosial di lingkuan kerja(4) Respon indivudu.

\section{Kepemimpinan Kepala Sekolah}

\section{a. Hakekat Kepemimpinan}

Pada dasarnya Islam memandang setiap manusia adalah pemimpin dan setiap pemimpin akan ditanya dan diminta pertanggungjawabannya diakhirat nanti. Manusia sebagai pemimpin minimal mampu memimpin dirinya sendiri. Hal ini sesuai dengan hadias nabi Muhammad SAW:

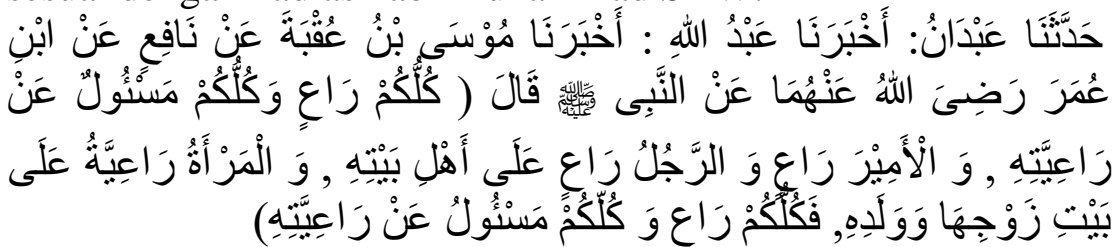

Adnan menyamaikan kepada kami dar Abdullah, dari Musa bin Uqbah, dari Nafi' dari Ibnu Umar bahwa Nabi bersabda," Setiap orang dari kalian adalah pemimpin, dan setiap orang kelak akan dipintai pertanggung jawabannya atas kepemimpinannya. Seorang Amir adalah pemimpin, seorang lelaki adalah pemimpin untuk keluarganya. Seorang Istri adalah pemimpin ( yang bertanggung jawab menjaga) rumah suami dan anak-anaknya. Setiap orang dari kalian adalah pemimpin, dan setiap orang kelak akan dipintai pertanggung jawabannya atas kepemimpinannya". ( HR. al-Bukhari dari Ibnu Umar)

Hadist tersebut memberikan gambaran bahwa setiap orang adalah pemimpin entah didalam sebuah organisasi, kelompok masyarakat, dalam ber- bangsa dan bernegara aatau paling tidak sebagai pemimpin dalam keluarga. Dan yang menjadi urgensi dalam hadist ini adalah bahwa setiap pemimpin akan dipintai pertanggung-jawaban atas kepemimpinannya. 
Pengaruh Kepemimpinan Kepala Sekolah dan Pengelolaan Kepegawaian Terhadap Penanggulangan Stres Guru ...

Kata kepemimpinan adalah terjemahan dari leadership yang berasal dari kata leader yang memiliki arti pemimpin. Pemimpin (leader) adalah orang yang memimpin, sedangkan pimpinan merupakan jabatannya. Dalam pengertian lain secara etimologi istilah kepemimpinan berasal dari kata "pimpin" yang artinya bimbing atau tuntun. Dari pimpin muncullah kata kerja memimpin yang artinya membimbing dan menuntun.

D.E Mc. Farland dalam sudaryono mengemukakan bahwa kepemimpinan adalah suatu proses di mana pemimpin di dilukiskan akan memberi perintah atau pengaruh, bimbingan atau proses mempengaruhi pekerjaan orang lain dalam memilih dan mencapai tujuan yang telah ditetapkan.

Kepemimpinan menurut Alan C Filley and Robert J. House dalam Mulkasir menyatakan bahwa "Leadership is a process whereby one person exert social influence over the member of a group". Kepemimpinan adalah proses di mana satu orang memberi pengaruh sosial atas anggota kelompok

Husaini Usman memberikan definisi kepemimpinan ialah ilmu dan seni mempengaruhi orang lain atau kelompok untuk bertindak sperti yang diharapkan untuk mencapai tujuan secara efektif dan efisien. Disebut ilmu karena ada teorinya, yaitu teori kepemimpinan. Disebut seni karena sama-sama mendapat ilmunya, tetapi dalam penerapan berbeda-beda tergantung pemimpinn, komitmen pengikut dna situasinya.

Stephen P. Robbins dan Timothy A. Judge mendefinisikan kepemimpinan sebagai kemampuan untuk memengaruhi suatu kelompok menuju pencapaian sebuah visi atau tujuan yang ditetapkan. Sumber dari pengaruh ini dapat secara formal, seperti yang dilakukan dengan peringkat manajerial di dalam organisasi.

Hadari Nawawi dalam Sudaryono mengatakan bahwa kepemimpinan dapat diartikan sebagai kemampuan atau kecerdasan mendorong sejumlah orang agar bekerjasama dalam melaksanakan kegiatan-kegiatan yang terarah pada tujuan bersama.

Dari beberapa definisi yang telah dipaparkan di atas memberikan gambaran yang cukup mendalam tentang kepemimpinan dan bisa memberikan kesimpulan; Pertama kepemimpinan merupakan upaya yang ditentukan oleh individu atau kelompok untuk mengkoordinasikan atau memberi arahan 
kepada individu atau kelompok pada suatau organisasi tertentu untuk mencapai tujuan yang ditetapkan. Kedua, prilaku pemimpin antara lain terlihat dalam bentuk memberi perintah, membimbing, dan mempengaruhi kelompok kerja atau orang lain dalam rangka mencapai tujuan tertentu secara efektif dan efisien. Ketiga, kegiatan seorang pemimpin dapat digambarkan sebagai seni dan bukan ilmu untuk mengkoordinasi dan memberi pengarahan kepada anggota kelompok. Keempat kepemimpinan adalah mengambil tanggung jawab, inisiatif dan keputusan dalam situasi sosial untuk membuat prakarsa baru, menentukan perencanaan kegiatan, dan segenap aktivitas lain, dan karena itu pula tujuan organisasi akan tercapai. Kelima seorang pemimpin hendaknya selalu bersama kelompok atau bawahannya dan menganggap bahwa kebersamaan adalah kekuatan.

\section{Pengelolaan Kepegawaian}

\section{a. Hakekat Pengelolaan}

Kata pengelolaan merupakan terjemahan dari kata "management", terbawa oleh derasnya arus penambahan kata serap ke dalam bahasa Indonesia, istilah Inggris tersebut lalu di Indonesiakan menjadi manajemen. Dalam kamus Besar Bahasa Indonesia kata "pengelolaan" terbentuk dari asal kata "kelola" yang berarti mengendalikan, menyelenggaraaan kemudian setelah memberikan awalan " penge" dan akhiran "an" menjadi pengelolaan yang mengandung arti "proses, cara, perbuatan mengelola; dan proses melakukan kegiatan tertentu dengan menggerakan tenaga orang lain".

Ara Hidayat dan Imam Machali mengungkapkan bahwa kata "management" memiliki beberapa arti yaitu, mengelola, menyelenggarakan, menjalankan, melaksanakan dan memimpin

Hal ini sesuai denga Firman Allah SWT/ 67:15 sebagai berikut,

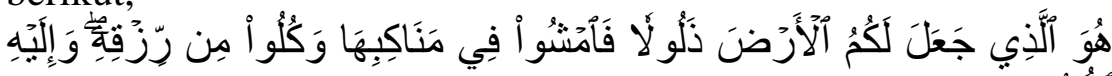

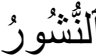

Dialah yang menjadikan bumi itu mudah bagi kamu, Maka berjalanlah di segala penjurunya dan makanlah sebahagian dari rezki-Nya. dan hanya kepada-Nya-lah kamu (kembali setelah) dibangkitkan.

Ayat ini memberiakan pengertian bahwa melalui ayat ini Allah mengajarkan kepada manusia dua hal Pertama Allah 
Pengaruh Kepemimpinan Kepala Sekolah dan Pengelolaan Kepegawaian Terhadap Penanggulangan Stres Guru ...

memerintahkan agar manusia berusaha dan mengelola sumber daya alam untuk kepentingan mereka guna memperoleh rezeki yang halal. Kedua karena berusaha dan mencari rezeki itu termasuk perintah Allah, maka orang yang mencari rezeki adalah orang yang mentaati Allah, dal hal itu termasuk ibadah.

Husaini Usman memaknai pengelolaan atau manajemen dalam arti luas sebagai perencaaan, pengorganisasian, pengarahan, dan pengendalian ( P4) suber daya organisasi untuk mencapai tujuan secara efektif dan efisien.

Ara Hidayat dan Imam Machali memberi definisi manajemen sebagai usaha mengatur organisasi untuk mencapai tujuan yang ditetapkan secara efektif, efisien, dan produktif. Efektif berarti mampu mencapai tujuan dengan baik ( doing the right thing ), sedangkan efisien berarti melakukan sesuatau dengan benar (doing thing right).

M. Manullang mendefinisikan manajemen personalia atau manajemen kepegawaian adalah "seni dan ilmu memperoleh, memajukan, dan memanfaatkan tenaga kerja sehingga tujuan organisasi dapat direalisasikan secara daya guna sekaligus adanya kegairahan bekerja dari para pekerja".

\section{b. Proses Rekrutmen (Recruitment Process)}

Rekrutmen adalah masalah penting dalam pengadaan tenaga kerja jika penariakn berhasil artinya banyak pelamar yang memasukan lamar-lannya, peluang untuk mendapatkan karyawan yang baik terbuka lebar, karena perusahaan dapat memilih yang terbaik dari yang baik. Oleh karena hal diatas bahwa proses rekrutmen adalah suatu proses mencari orang yang tepat dan bertanggung jawab yang menjadi dasar dari apa yang mereka akan dapatkan.

Dalam proses rekrutmen menurut Raymond et, all dalam Farid Poniman dan Yayan Hidayat ada beberapa faktor yang berpengaruh yaitu:1) ketersediaan posisi yang ditawarkan (Job Choice); 2) Karakteristik Posisi ( Vacancy Caracteristic); 3) Sumber Rekrutmen (Recruitment sources); 4) Karakteristik para Pelamar ( Applicant Caracteristic); 5) Kebijakan Personalia ( Personnel Policy);6) Sipat dan perilaku Rekruter ( Recruiter Trait and Behavior) 


\section{c. Proses Seleksi}

Proses seleksi yaitu dilakukan setelah kegiatan rekrutmen berakhir. Kegiatan rekrutmen didukung dengan proses seleksi. Proses seleksi adalah kegiatan mengumpulkan informasi untuk menentukan siapa yang akan dipekerjakan atau diterima sebagai karyawan perusahaan atau suatu organisasi kependidikan, dengan mengacu kepada recana SDM perusahaan, spesifikasi jabatan, ketentuan hukum, prosedur yang berlaku, dan juga kepentingan karyawan itu sendiri.

Seleksi adalah suatu kegiatan pemilihan dan penentuan pelamar yang diterima atau ditolak untuk menjadi karyawan dalam sebuah peusahaan atau lembaga pendidikan. Seleksi didasarkan kepada spesifikasi tertentu dari dari setiap perusahaan bersangkutan

\section{d. Penempatan}

Penempatan karyawan adalah tindak lanjut dari seleksi, yaitu menempatakan calon tenaga kerja yang diterima atau lulus seleksi pada jabatan atau pekerjaan yang membutuhkannya dan sekaligus mengutus dan menugaskan calon tenaga kerja tersebut. Penemptan karyawan harus didasarkan pada job description dan job specification yang telah ditentukan serta berpedoman kepada prinsip manajemen, Hasibuan dalam Suparno Eko Widodo mengatakan "Penempatan orang-orang yang tepat pada tempat yang tepat dan penempatan orang yang tepat untuk jabatan yang tetap". Allah berfirman al- An'âm/6:135

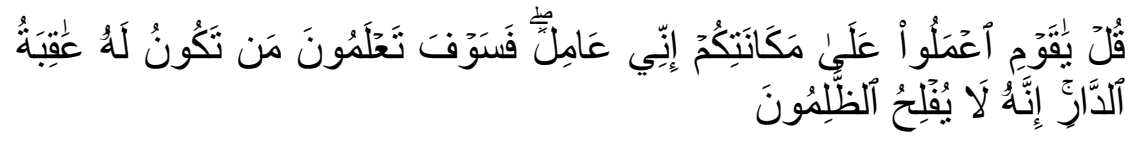

Katakanlah: "Hai kaumku, berbuatlah sepenuh kemampuanmu Sesungguhnya akupun berbuat (pula). kelak kamu akan mengetahui, siapakah (di antara kita) yang akan memperoleh hasil yang baik di dunia ini. Sesungguhnya orangorang yang zalim itu tidak akan mendapatkan keberuntungan.

Ayat ini memberikan pengertian agar seseorang bekerja dengan professional dan mencurahkan kemampuannya jika ia tidak mampu melakukan tugasnya sendiri dia bisa mencari orang lain ( tenaga kerja) yang dianggap mampu untuk melakukan pekerjaan pekerjaan atau tugas tersebut. 
Pengaruh Kepemimpinan Kepala Sekolah dan Pengelolaan Kepegawaian Terhadap Penanggulangan Stres Guru ...

\section{e. Pemberdayaan dan Pengembangan Personel}

Pemberdayaan adalah salah satu upaya agar karyawan atau pegawai tidak memiliki rasa kebergantungan kepada atasannya dalam melaksanakan kinerjanya. Kebergantungan ini sangat tidak baik bagi seorang tenaga kerja sebab akan melahirka siakap menunggu intruksi dari atasan saja tanpa dia mau berfikir, berinisiatif tentang hal apa yang harus dia lakuakan dalam menjalankan serta menyelesaikan tugasnya. Melalui proses ini seorang pegawai atau tenaga kerja dituntut untuk memiliki rasa tanggung jawab terhadap pekerjaannya. Dalam pemberdayaan juga dibangun kegiatan mentranfer pengarahan yang datang dari sumber luar kepada individu didalam melakukantugas dan tanggung jawabnya. Jadi proses pemberdayaan berkaitan dengan memberikan kemampuan dan wewenang kepada individu untuk dapat mengambil keputusan sendiri tanpa bergantung kepada atsannya.

\section{f. Promosi Pegawai}

Promosi berarti penghargaan berupa pemberian kenaikan jabatan, yakni menerima kekuasaan dan tanggung jawab yang lebih besar dari kekuasaan dan tanggung jawab sebelumnya. Pemberian promosi kepada seorang pegawai, berarti memberikan penghargaan kepadanya atas dasar bahwa pegawai tersebut memiliki kinerja dan prestasi yang baik.

Arun Manoppa dan Mirzas Saiyadim dalam M. Manullang merumuskan promosi sebagai berikut: Promotion is the upward reassignment of an individual in an organization's hieracky accompanied by increased responsibilities, enhanced status, and usually with increased income, though not always so.

\section{g. Demosi Pegawai}

Sebagai lawan promosi adalah demosi atau penurunan pegawai. Demosi adalah penurunan jabatan dalam suatu instansi yang biasa dikarenakan oleh berbagai hal, contohnya adalah keteledoran dalam bekerja. Turun jabatan biasanya diberikan pada karyawan yang memiliki kinerja yang kurang baik atau buruk serta bisa juga diberikan ada karyawan yang bermasalah sebagai sanksi hukuman Demosi merupakan suatu hal yang sangat dihindari oleh setiap pekerja karena dapat menurunkan sta tus, jabatan, dan gaji. Namun, demosi atau turun jabatan ini biasa dilakukan oleh beberapa instansi ataupun perusahaan demi 
peningkatan kualitas kerja, dan juga sebagai motivasi bagi karyawannya agar mau berusaha untuk memperoleh yang diinginkan. Mendapatkan promosi dan menghindari demosi.

\section{h. Pemberhentian}

Pemberhentian adalah fungsi operatif terakhir manajemen sumber daya manusia. Istilah pemberhentian sinonim dengan separation, pemisahan atau pemutusan hubungan kerja (PHK) karyawan dari suatu organisasi perusahaan. Fungsi pemberhentian harus mendapat perhatian yang serius dari manajer/ pimpinan karena telah diatur oleh undang-undang dan membarikan resiko bagi perusahaan/ organisasi maupun karyawan bersangkutan. Pemberhentian harus sesuai dengan undang-undang No. 12 Tahun 1964 KUHP. Pemberhentian juga harus memperhatikan pasal 1603 ayat 1 KUHP yaitu mengenai " tenggang waktu saat dan izin pemberhentian".

Pemberhentian adalah pemutusan hubungan kerja seseorang karyawan dengan suatu organisasi bisa perusahaan atau lainnya seperti sekolah. Dengan pemberhentian berarti berakhirnya keterikatan kerja karyawan terhadap perusahaan atau tmpat dia bekerja.

\section{Metode Penelitian}

Metode Penelitian dalam pengertian yang luas dapat diartikan sebagai cara ilmiah, untuk mendapatkan data dengan tujuan dan kegunaan tertentu. Sugiyonomengemukakan bahwa ada empat kata kunci yang perlu diperhatikan dalam menjelaskan metode penelitian, yaitu: cara ilmiah yang berarti kegiatan penelitian itu dilakukan berdasarkan pada karakteristik keilmuan, yakni rasional, emparis dan sistematis. Rasional yang berarti kegiatan penelitian itu dilakukan dengan cara-cara yang masuk akal, sehingga terjangkau oleh penalaran manusia. Empiris, yakni cara-caraa yang dilakukan dalam penelitian dapat diamati oleh indera manusia, sehingga orang lain dapat mengamati dan mengetahui cara-cara yang digunakan. Sistematis, artinya proses yang digunakan dalam penelitian ini menggunakan langkah-langkah tertentu yang bersifat logis. Walaupun langkahlangkah penelitian antara metode kuantitatif, kualitatif dan Research and Developement (R\&D) berbeda, akan tetapi seluruhnya sistematis.

Menilik uraian di atas, dan sesuai tingkat kealamiahan tempat penelitian, maka metode dalam penelitian ini mengunakan metode survai dengan pendekatan korelasional. Metode survai dipergunakan 
Pengaruh Kepemimpinan Kepala Sekolah dan Pengelolaan Kepegawaian Terhadap Penanggulangan Stres Guru ...

dengan pertimbangan-pertimbangan bahwa penelitian dilakukan untuk mendapatkan data setiap variabel masalah penelitian dari tempat tertentu yang alamiah (bukan buatan) dengan alat pengumpul data berbentuk angket (kuesioner). Populasi dalam penelitian ini adalah 140 orang guru dengan sampel terjangkau 104 orang guru. Sumber data yang digunakan dalam penelitian ini adalah guru pada Sekolah Menengah Atas yang berada dalam naungan Dinas Pendidikan Kabupaten Bogor. Dengan menggunakan teknik proporsional random sampling peneliti menggunakan data yang diperoleh dari guru SMA swasta yang berada di Sub Rayon 11 Parung Kabupaten Bogor terdiri dari, SMA School of Universe, SMA Al- Mukhlisin, SMA Riyadhlul Jannah dan SMA Al-Ashriyyah Nurul Iman.

\section{Hasil dan Pembahasan}

\section{Pengaruh Kepemimpinan Kepala Sekolah terhadap Penanggulangan Stres Guru}

Berdasarkan pengujian hipotesis menujukkan bahwa terdapat pengaruh yang positif dan signifikan antara kepemimpinan kepala sekolah terhadap Penanggulangan stres guru pada empat sekolah menengah atas sub rayon 11 parung yang telah ditentukan. Hal ini ditunjukan oleh kekuatan pengaruh atau koefisien korelasi sebesar 0,660 pada tingkat kepercayaan $99 \%(\alpha=0.01)$, sedangkan besarnya pengaruh atau koefisien determinasi R-square sebesar 0,436 yang berarti bahwa kepemimpinan kepala sekolah memberikan pengaruh pengelolaan stres guru sebesar 43,6\% dan berarti sisianya 56,4\% ditentukan oleh faktor lainnya. Untuk arah pengaruh atau koefesien regresi diproleh $\hat{Y}=55,886+0,531 \mathrm{X}_{1}$ yang berarti bahwa setiap peningkatan satu unit skor kepemimpinan kepala sekolah mempengaruhi peningkatan skor Penanggulangan stres guru sebesar 0,531 (korelasi kuat).

Berdasarkan analisis tersebut bahwa kepemimpinan kepala sekolah merupakan salah satau faktor yang mempengaruhi stres guru. Semakin baik kepemimpinan kepala sekolah akan diikuti dengan semakin menurunkan stres guru.

\section{Pengaruh Pengelolaan Kepegawaian terhadap Penanggulangan Stres Guru}

Berdasarkan pengujian hipotesis menujukkan bahwa terdapat pengaruh yang positif dan signifikan antara pengelolaan 
kepegawaian dengan penanggulangan stres guru pada empat sekolah menengah atas sub rayon 11 parung yang telah ditentukan. Hal ini ditunjukan oleh kekuatan pengaruh atau koefisien korelasi sebesar 0, 694 pada tingkat kepercayaan 99\% $(\alpha=0.01)$, sedangkan besarnya pengaruh atau koefisien determinasi R-square sebesar 0 , 481 yang berarti bahwa pengelolaan kepegawaian memberikan pengaruh dengan penanggulangan stres guru sebesar 48,1\% dan sisanya yaitu $51,9 \%$ ditentukan oleh faktor lainnya. Untuk arah pengaruh atau koefesien regresi $\hat{Y}=50,334+0,572 \mathrm{X}_{2}$ yang berarti bahwa setiap peningkatan satu unit skor pengelolaan kepegawaian mempengaruhi peningkatan skor penanggulangan stres guru sebesar 0,572 (korelasi kuat).

Manajemen kepegawaian yang baik memiliki pengaruh dalam menyelesaikan permaslahan yang membuat pegawai mengalami stres khusunya bagi permasalahan yang dihadapi guru.

Berdasarkan analisis tersebut bahwa pengelolaan kepegawaian merupakan salah satau faktor yang mempengaruhi penanggulangan stres guru. Peningkatan mutu pengelolaan kepegawaian akan diikuti dengan menurunnya stres guru.

\section{Pengaruh Kepemimpinan kepala Sekolah dan Pengelolaan Kepegawaian Secara Bersama-sama terhadap Penanggulangan Stres Guru}

Pengaruh kedua variabel independen kepemimpinan kepala sekolah dan pengelolaan kepegawaian secara simultan terhadap penanggulangan stres guru menujukkan adanya pengaruh yang positif dan signifikan. Jadi pada permasalahan yang sedang diteliti diketahui bahwa secara simultan kedua variabel independen atau bebas (kepemimpinan kepala sekolah dan pengelolaan kepegawaian) memiliki pengaruh yang positif dan signifikan terhadap kinerja pada empat sekolah menengah atas sub rayon 11 parung yang telah ditentukan.

Hal ini dapat dilihat dari kekuatan pengaruh koefisen korelasi $=0,706$ yang berarti bahwa kepemimpinan kepala sekolah dan pengelolaan kepegawaian secara bersamaan terhadap penanggulangan stres guru. Sedangkan besarnya pengaruh koefesien determinasi R-square sebesar 0,499 yang berarti bahwa besarnya pengaruh kepemimpinan kepala sekolah dan pengelolaan kepegawaian secara bersamaan dengan penanggulangan stres guru sebesar $49,9 \%$ dan sisanya yaitu $50,1 \%$ ditentukan oleh faktor 
Pengaruh Kepemimpinan Kepala Sekolah dan Pengelolaan Kepegawaian Terhadap Penanggulangan Stres Guru ...

lainnya. Adapun arah pengaruh persaman regresi $\hat{Y}=47,229+$ $0,205 X_{1}+0,394 X_{2}$ yang berarti bahwa setiap peningkatan satu unit skor independen kepemimpinan kepala sekolah dan pengelolaan kepegawaian secara bersamaan mempengaruhi peningkatan skor penanggulangan stres guru sebesar 0,205+0,394 $=0,599$ (korelasi kuat).

Jika dilihat dari nilai R-square di atas maka secara bersamasama variabel kepemimpinan kepala sekolah dan pengelolaan kepegawaian atau variabel independen memberikan kontribusi atau pengaruh terhadap penanggulangan stres guru pada sekolah menengah atas sub rayon 11 parung dan sisanya merupakan pengaruh faktor lain diluar kedua variabel bebas yang diteliti. Jadi meningkat dan menurunnya stres guru tidak hanya dipengaruhi oleh kepemimpinan kepala sekolah dan pengelolaan kepegawaian saja akan tetapi bisa juga dipengaruhi oleh faktor-faktor lainnya.

\section{E. Penutup}

\section{Kesimpulan}

Berdasarkan hasil penelitian dan pembahasan, maka dapat disimpulkan beberapa hal sebagai berikut:

a. Terdapat pengaruh yang positif dan signifikan antara kepemimpinan kepala sekolah terhadap pengelolaan stres guru pada sekolah menengah atas sub rayon 11 parung. Hal ini ditunjukan oleh kekuatan pengaruh atau koefisien korelasi sebesar 0,660 pada tingkat kepercayaan 99\% $(\alpha=0.01)$, sedangkan besarnya pengaruh atau koefisien determinasi $\mathrm{R}$ square sebesar 0,436 yang berarti bahwa kepemimpinan kepala sekolah memberikan pengaruh pengelolaan stres guru sebesar $43,6 \%$ dan berarti sisianya $56,4 \%$ ditentukan oleh faktor lainnya. Untuk arah pengaruh atau koefesien regresi diproleh $\hat{Y}=55,886$ $+0,531 X_{1}$ yang berarti bahwa setiap peningkatan satu unit skor kepemimpinan kepala sekolah mempengaruhi peningkatan skor pengelolaan stres guru sebesar 0,531 (korelasi kuat).

b. Terdapat pengaruh yang positif dan signifikan antara pengelolaan kepegawaian terhadap pengelolaan stres guru pada sekolah menengah atas sub rayon 11 parung. Hal ini ditunjukan oleh kekuatan pengaruh atau koefisien korelasi sebesar 0, 694 pada tingkat kepercayaan $99 \%(\alpha=0.01)$, sedangkan besarnya pengaruh atau koefisien determinasi R-square sebesar 0,481 
yang berarti bahwa pengelolaan kepegawaian memberikan pengaruh dengan pengelolaan stres guru sebesar $48,1 \%$ dan sisanya yaitu $51,9 \%$ ditentukan oleh faktor lainnya. Untuk arah pengaruh atau koefesien regresi $\hat{Y}=50,334+0,572 \mathrm{X}_{2}$ yang berarti bahwa setiap peningkatan satu unit skor pengelolaan kepegawaian mempengaruhi peningkatan skor pengelolaan stres guru sebesar 0,572 (korelasi kuat).

c. Terdapat hubungan yang positif dan signifikan antara kepemimpinan kepala sekolah dan pengelolaan kepegawaian secara bersama- sama terhadap pengelolaan stres guru pada sekolah menengah atas sub rayon 11 parung. Hal ini dapat dilihat dari kekuatan pengaruh koefisen korelasi $=0,706$ yang berarti bahwa kepemimpinan kepala sekolah dan pengelolaan kepegawaian secara bersamaan terhadap pengelolaan stres guru. Sedangkan besarnya pengaruh koefesien determinasi R-square sebesar 0,499 yang berarti bahwa besarnya pengaruh kepemimpinan kepala sekolah dan pengelolaan kepegawaian secara bersamaan dengan pengelolaan stres guru sebesar 49,9\% dan sisanya yaitu 50,1\% ditentukan oleh faktor lainnya. Adapun arah pengaruh persaman regresi $\hat{Y}=47,229+0,205 X_{1}+0,394 X_{2}$ yang berarti bahwa setiap peningkatan satu unit skor independen kepemimpinan kepala sekolah dan pengelolaan kepegawaian secara bersamaan mempengaruhi peningkatan skor pengelolaan stres guru sebesar 0,205+0,394 $=0,599$ (korelasi kuat).

\section{Saran}

Berdasarkan hasil temuan penelitian menunjukkan adanya pengaruh yang positif dan signifikan antara kepemimpinan kepala sekolah dan pengelolaan kepegawaian secara bersama- sama terhadap stres guru pada sekolah menengah atas sub rayon 11 parung, maka peneliti menyarankan sebagai berikut:

a. Diperlukan adanya usaha dan upaya dari pihak lembaga dan dari pihak pimpinan, dalam rangka menghindari stres yang bisa saja dialami oleh para guru dengan cara meningkatkan kemampuan memimpin, memberi perhatian, memfasilitasi, serta berupaya mensejahterakan guru- guru mana mereka sangat ingin meningkatkan pendidikan dengan cara menjadi tenaga pendidik yang baik, namun penghargaan bagi guru- guru yang berprestasi dalam mengharumkan nama lembaga atau sekolah dan menerapkan serta meningkatkan standar pengelolaan kepegawaian adalah hal yang harus diperhatikan . 
Pengaruh Kepemimpinan Kepala Sekolah dan Pengelolaan Kepegawaian Terhadap Penanggulangan Stres Guru ...

b. Pekerjaan yang dilakukan dan dihasilkan guru perlu dihargai, fasilitas yang diinginkan mencukupi, serta terdapat pengakuan terhadap prestasi guru di sekolah agar guru terpuaskan dengan apa yang di dapatnya di tempat kerja. Dengan demikian tentunya guru akan melaksanakan tugasnya dengan penuh tanggung jawab dan maksimal.

c. Kepala sekolah hendaknya meningkatkan kemampuan dirinya sebagai seorang pemimpin terlebih lagi dalam keprofesionalannya, hal ini menjadi penunjang dirinya dalam menjalankan tugas sebagaimana mestinya sehingga pelaksanaan semua kegiatan disekolah akan berjalan dengan baik dan mencapai tujuannya.

\section{Daftar Pustaka}

Badan Litbang dan Diklat Kementrian Agama RI, Tafsir Al-Quran Tematik, Jakarta: Kamil Pustaka, 2017 ,cet IV.

Bangkit, Sandi. Manajer Sukses Segala Hal tentang Manajer dan Kepemimpinan, Yogyakarta: Kobis, 2015.

Bernawai dan Muhammad Arifin, Instrumen Pembinaan, Peningkatan, dan Penilaian kinerja Guru Profesional, Yogyakarta: Ar-Ruzz Media, 2012 , Imâm Abî Abdillah Muhammad bin Ismaîl bin Ibrâhîm bin alMughîrah bin Bardizbah Shahîh Bukhârî, Kairo: Maktabah alSalafîyah, 1400 h, Juz 4, h. 190, no. hadits 6496, bab Raf'ul Amânah.

Colquit, Jason A. et.al , Organizational Behavior, Improving, Performance and Commitment in the Workplace, New York: McGraw Hill, 2011.

, Jason A., Jeffrey A. Lepine dan Michael J. Wesson. Organizational Behavior Improving Performance and Commitment in Workplace. New York: McGraw-Hill, 2011.

Departemen Pendidikan Nasional, Kamus Besar Bahasa Indonesia Pusat bahasa, Jakarta: Gramedia Pustaka utama, cet I, edisi IV, 2008.

Echols, John M, Hassan Shadily. Kamus Inggris Indonesia and English Indonesia Dictionary. Jakarta: Gramedia Pustaka Utama, 2005.

Gibson, James L., at. al., Organizations, Behavior, structure, Processes, New York: McGraw-Hill, 2012. 
Hasbullah ,M. Kebijakan Pendidikan, dalam Perspektif Teori, Aplikasi, dan Kodisi Objektif Pendidikan di Indonesia Jakarta: Raja Grafindo Persada, 2015.

Hasibuan, Malayu S. P. Manajemen Sumber Daya Manusia. Jakarta: Bumi Aksara, 2014.

, Malayu S. P. Organisasi dan Motivasi: Dasar Peningkatan Produktivitas. Jakarta: Bumi Aksara, 2005.

Hidayat, Ara. et.all., Pengelolaan Pendidikan Konsep Prinsip dan Aplikasi Dalam Mengelola Sekolah dan Madrasah, Yogyakarta: Kaukaba, 2012.

Hude, Darwis. Emosi Penjelajahan Religoi-Psikologis Tentang Emosi Manusia di dalam Al-Qur'an, Jakarta: Erlangga, 2006.

Inge, Nefri. "Mendikbud Akui Permasalahan Pelik Guru Honorer Di Indonesia

"http://regional.liputan6.com/read/2894934/mendikbud-akuipermasalahan-pelik-guru-honorer-di-indonesia. dalam

Kartika , Unoviana " 5 Jenis Strses yang Perlu Anda Tahu" https://health.kompas.com/read/2013/06/26/1256093/5.Jenis.Stres.yang .Perlu.And Tahu.

Komarudin, Ukim. Arief Rachman: Guru, Jakarta: Erlangga, 2015.

Luthans, Fred. Organizational Behavior: An Avidence-Based Approach. New York: Mc Graw-Hill, 2011, hal. 279.

Manullang, M. Management Personalia, Balai Aksara- Yudistira, Pusttaka saadiyah, Jakarta, cet, XI 1987.

Maulipaksi, Desliana. 7 Provinsi Raih Nilai Terbaik Uji Kompetensi

Guru 2015 https://www.kemdikbud.go.id/main/blog/2016/01/7provinsi-raih-nilai-terbaik-uji-kompetensi-guru-2015.

Mulkanasir, Administration and Management Leadership Sebuah Upaya Mempercepat Tercapainya Tujuan Organisasi Secara Efektif, Bogor: Atma Kencana Publishing, 2011.

Nisrina, "Langkah dan cara pengelolaan stres dalam pekerjaan," dalam. https://pioupj.wordpress.com/2017/03/21/langkah-dancara-pengelolaan-stress-dalam-pekerjaan/.

Permadi , Dadi, Kepemimpinan Mandiri profesional Kepala Sekolah, Jakata: Bandung, 2011. 
Pengaruh Kepemimpinan Kepala Sekolah dan Pengelolaan Kepegawaian Terhadap Penanggulangan Stres Guru ...

Poniman, Farid dan Yayan Hidayat, Manajemen HR STIF In Terobosan untuk mendongkrak Produktifitas, Jakarta: Gramedia pustaka utama, 2015.

Robbins. P. Stephen dan Timothy A. Judge, Perilaku

Organisasi, penterjemah, Ratna Saraswati dan Febrille Sirait, Jakarta: Salemba Empat, 2015.

Sandra , Rober dan Ifdil, Konsep Kerja Guru Bimbingan dan Konseling Jurnal Pendidikan Indonesia, Indonesian Institute for Counseling, Education and Therapy Volume 1 Nomor 1, Oktober 2015.

Sudaryono, Leadership Teori dan Praktek Kepemimpinan, Jakarta: Lentera Ilmu Cendekia, 2014.

Sugiyono, Metode Penelitian Pendidikan ,Pendekatan, Kuantitatif, Kualitatif dan R\&D, Bandung: Alfabeta, 2010.

Usman, Husaini Manajemen, Teori dan praktik, Riset pendidikan, Jakarta:Bumi Aksarahal, 2011. 
Muhammad Mudzakkir

154 | Al Ashriyyah, Vol.5 No.1 Mei 2019 